\title{
Changes in a hydrographic network of the Słowiński National Park in terms of photogrammetric analyses
}

\section{Abstract}

The main objective of this study is to evaluate the changes in the hydrographic network of Słowiński National Park. The authors analysed the changes occurring in the drainage network due to limited maintenance in this legally protected natural area. To accomplish this task, elaborations prepared on the basis of aerial photographs were used: an orthophoto map from 1996, hyperspectral imaging from June 2015, and a digital terrain model based on airborne laser scanning (ALS) from June 2015. These spatial data resources enabled the digitisation of the water courses for which selected hydro-morphological features had been defined. As a result of analysing the differences of these features, a quality map was elaborated which was then subjected to interpretation, and the identified changes were quantified in detail.

Keywords

Morphology • Wetlands • Słowiński National Park • Remote Sensing • Protected areas

(C) University of Warsaw - Faculty of Geography and Regional Studies
Maciej Góraj ${ }^{1}$, Marcin Kucharski ${ }^{1}$ Krzysztof Karsznia ${ }^{2}$, Izabela Karsznia ${ }^{3}$, Jarosław Chormański ${ }^{1}$

'Division of Hydrology and Water Resources, Department of Hydraulic Engineering, Faculty of Civil and Environmental Engineering, Warsaw University of Life Sciences, Poland e-mail: m.goraj@levis.sggw.pl e-mail: marcinkucharski00@gmail.com e-mail: j.chormanski@levis.sggw.pl

${ }^{2}$ Division of Geodesy and Spatial Planning, Department of Civil Engineering.

Faculty of Civil and Environmental Engineering

Warsaw University of Life Sciences, Poland

e-mail: krzysztof_karsznia@sggw.pl

${ }^{3}$ Department of Geoinformatics,

Cartography and Remote Sensing,

Faculty of Geography and Regional Studies,

University of Warsaw, Poland

e-mail: i.karsznia@uw.edu.pl

Received: 5 May 2017

Accepted: 1 August 2017

In the case of wetlands protection, in terms of the performance supporting the revitalization of lost habitats, the reduction of drainage network can be mentioned. Under such conditions, however, the occurrence of spontaneous re-naturalization may be possible (Nawrocki 2011). Consequently, the evaluation of such actions should include the detection of changes in the hydrographic network. There are various types of such tests. Some researchers base their analysis on a comparison of historical maps to the current situation (Ptak et al. 2012; Przybycin \& Hildebrandt-Radke 2011; Gesch et al. 2013). Others use materials obtained from airborne scanning (Gesch et al. 2013) or satellite imaging (Zaigham \& Mahar 2015).

The main hypothesis of the following research is that it is possible to detect the re-naturalization processes in anthropogenic converted areas using aerial images. The aim is to detect watercourses which have been subjected to re-naturalization processes. The detection of the effects of these processes could constitute the evidence needed to confirm the hypothesis.

One of the basic assumptions is that the re-naturalization processes could be visible, especially in the watercourses that have been unmaintained over an extended period, where anthropogenic manipulations are very infrequent. If manipulations in the protected areas are rare, it probably is possible to detect significant differences between paths both inside and outside the protected areas. These differences could take miscellaneous forms. The most important forms for the aerial image interpretation are the symptoms seen on a relatively large scale, such as degeneration of strict geometrical shape or changes in the width of the channel. 
MISCELLANEA GEOGRAPHICA - REGIONAL STUDIES ON DEVELOPMENT

Vol. $21 \cdot$ No. 4 • 2017 • pp. 197-204 • ISSN: 2084-6118 • DOI: 10.1515/mgrsd-2017-0019

Methods

Study Area

The study area is located within Słowiński National Park and its legally protected surroundings, which are situated in northern Poland, Pomeranian Province, in the counties of Słupsk and Lębork (municipalities of Ustka, Smołdzino, Główczyce, Wicko and Leba). The Park was erected by the Polish Council of Ministers on November 11, 1966. It consists of two districts: land and water. The land district covers an area of 10,821 ha. The water district consists of Gardno and Łebsko regions with a total area of 10,097 ha, including part of the Baltic Sea region of 11,171 ha. The land district includes the regions of Rąba, Smołdzino, Smołdziński Forest, Rowy, Żarnowska and Kluki (Słowiński National Park in 2015; Adrian 2013).

The presented studies were carried out within the abovementioned protected areas of land district, as well as within the water district (Figure 1). The preventative actions undertaken by the National Park include the wide-understood protection of nature, including the active protection of valuable natural habitats - especially the Baltic Sea, dunes, lakes and wetlands (Słowiński National Park 2015). The wetland habitats of Słowiński National Park are among the least susceptible to conservation efforts, as a result of the specificity of economic transformation in the past - this refers to large-scale basic and detailed reclamations preparing the whole area for intensive forestry and agricultural use (Utracka-Minko \& Stańko 2005).

Currently, the main hazard concerning the wetlands is the factor of the strongly transformed water conditions resulting from the drainage implemented during the post-war period. The protection of these habitats is additionally complicated by the contemporary mining activity - the 'Krakulice' peat mine is located in the vicinity of the protected area of Żarnowska. As part of the active protection of habitats in Słowiński National Park, several actions were undertaken aimed at the reclamation of the wetlands. Above all, the operation and maintenance of the drainage network were significantly reduced, leading to a simultaneous increase in the groundwater level. The main objective of this work was halting the progressive drying of peat bogs and the decay of peat tracks (Utracka-Minko \& Stańko 2005).

Regarding the studies on peat and the radiocarbon dating performed for Słowiński National Park, it can be concluded that, prior to the period of intensive drainage - from about the thirteenth century - the Park wetlands had mostly appeared in the form of a high peat bog. In this area, there was a thin layer of high peat formed in older fractions and associated with groundwater (Mocek 1978; Mocek et al. 1997).

The first attempts to change the water conditions by constructing drainage systems occurred in the period 1750-1800. This resulted in the founding of Łebski Channel, Gardno-Łebsko Channel, Żarnowski Channel and Łupawa-Łebsko Channel. The second period of intensive drainage works, mainly of a reconstructive nature, happened between 1840 and 1880. In the post-war period (1965-1993), an attempt was made to adapt the wet area of the contemporary Słowiński National Park to the requirements of intensive forestry and agriculture (Chlost 2013). In order to achieve an improvement in the Park's hydrographic network, the natural watercourses were adjusted to the increased transit of drainage water. Furthermore, numerous new reclamation elements (basic and detailed), such as ditches and canals, were added to the network (Utracka-Minko \& Stańko 2005).

Since the nineties, when the general attitude changed and increased efforts to protect the habitats subjected to degradation began to be observed, the maintenance activities related to the drainage network have gradually decreased. In the twenty-first century, efforts have been made to raise the groundwater level within the Park. The activities undertaken to this end involved increasing the groundwater level and protecting the natural peat (Utracka-Minko \& Stańko 2005).

\section{Source data}

In this study, an aerial orthophoto map from 1996, an aerial near infra-red orthophoto map and a digital terrain model (DTM performed by MGGP Aero) from 2015 were used. The 'orthophoto map 1996', with a spatial resolution of $50 \times 50 \mathrm{~cm}$, was acquired from the resources of the Chief Documentation Centre of Geodesy and Cartography.

An aerial near infra-red picture (spatial resolution $15 \times 15 \mathrm{~cm}$ ) from 2015 was made by the same company as the orthophoto map, using the airborne laser scanning (ALS) technique. The picture was taken in near infrared. The main advantage of this image is its high sensitivity to humidity changes. Thus, the areas of high humidity are shown as grey-blue.
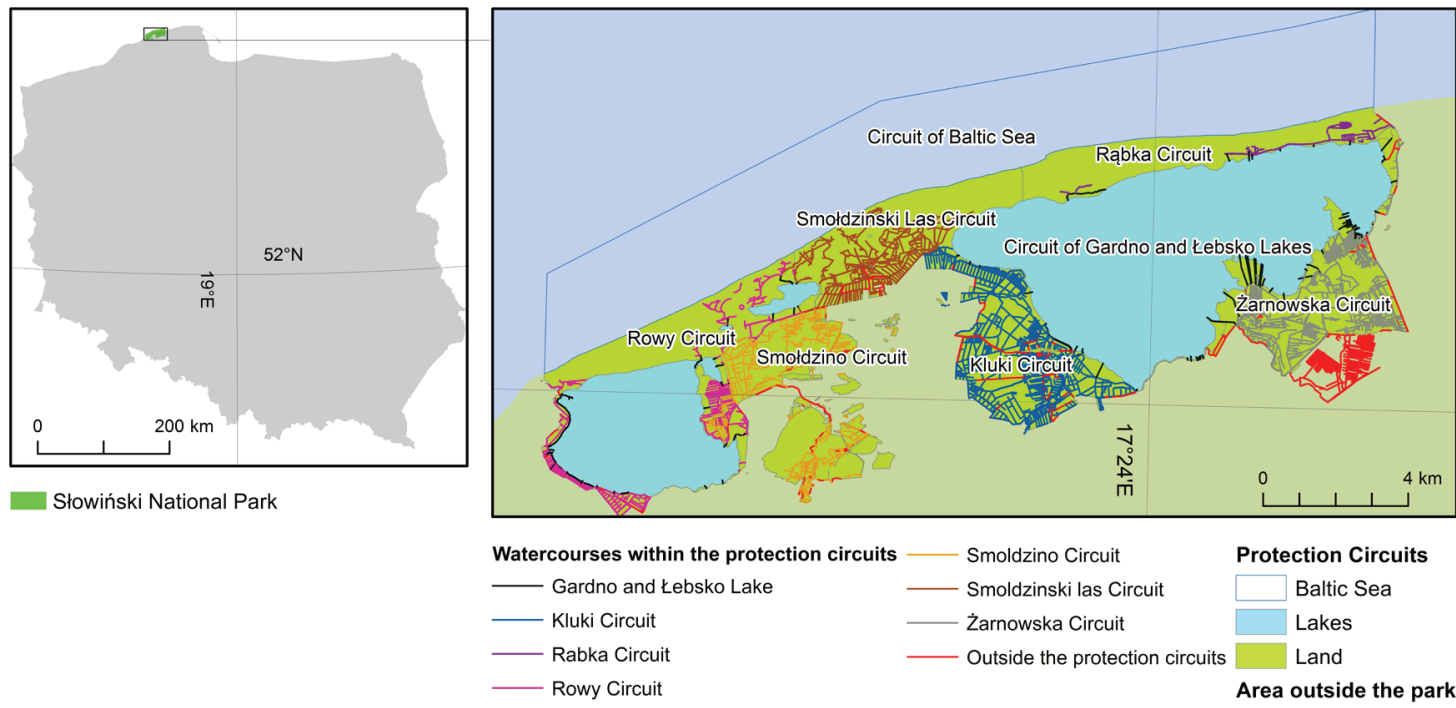

Protection Circuits

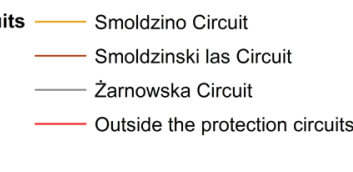

Baltic Sea

Lakes

Land

Figure 1. Watercourses within the protection circuits (designed by M. Góraj) 
The digital terrain model (DTM) was provided by MGGP Aero, also using ALS. Its spatial resolution is $50 \times 50 \mathrm{~cm}$. The use of DTM allows the precise geometric interpretation of threedimensional terrain objects such as roads and paths.

The Polish Hydrographic Map (MPHP in a scale of 1:10 000) (Barszczyńska et al 2013) was used as the source of knowledge about the approximate location of the paths.

\section{Digitizing the hydrography network}

The study focuses on changes in the hydrographic network (natural and anthropogenic paths) within six land protection zones. A control group consisting of watercourses situated near the protection zones was additionally included in the research. By using both the near infra-red image and the DTM, the courses located within the study area were digitized. MPHP was used as a watercourse database. Paths were located without accurate location. The DTM was considered the main source of information about the course geometry. Furthermore, the ArcGIS software was used to determine the layer of declines. In this layer, a pixel represented a declining value measured in degrees. Next, using map algebra (raster calculator tool), the area of decrease greater than or equal to 1 degree was identified. This layer allowed the estimation of the actual geometry of the water system in the plan and its approximate width.

The near infra-red image was characterized by high spatial resolution, as well as a very good legibility of information on water existence within a grid cell. This was a key source which served to prepare the layer of streams occurring in the Park. By using this layer, the streams located in the study area were vectorised.

Combining the advantages of the DTM and near infra-red images, the water course traces were defined, thereby creating a layer containing line objects. This database contained information about the location and geometry of watercourse sections, including their width and depth.

Description of selected morphology properties of watercourses

Based on the source material, an interpretation was performed of selected morphological features of the watercourses (namely, their status and the presence of water). The paths mentioned in MPHP were detected on the orthophoto maps and the DTM. The partitioning of the watercourses was the same as in MPHP, which means that one watercourse is a section between two characteristic points (e.g. the mouth of the tributary). The state of the watercourse was evaluated by using the visual interpretation of the orthophoto map and the DTM and then, based on the authors' classification scheme, the watercourse was classified into one of the following classes:

- maintained,

- periodically overgrown,

- overgrown,

- disappearing,

- bushy,

- wooded,

- underground.

The followed classification was performed for the dataset from 1996 and 2015.

A 'maintained' watercourse is a track where the channel is permanently enabled for water transport. It has been cleaned periodically and the vegetation growing in it does not exceed $20 \%$ of the watercourse surface. Its banks are clearly visible on the DTM.

A 'periodically encroached' watercourse is one that has not been subjected to maintenance work for a long time. Its channel is covered in vegetation in the range of $20-60 \%$. These plants represent a hydraulic barrier to the flow of water, causing the local accumulation of groundwater. The banks of this stream visible on the DTM are irregular and difficult to see locally.

The channel of an 'overgrown' watercourse is covered by vegetation in the range of $60-100 \%$. This type of watercourse can hardly transport water. The vegetation present in the riverbed causes considerable inconvenience of flow, which leads to the accumulation of water, especially in front of obstacles such as highly-developed clumps of aquatic vegetation. The banks of these streams are visible on the DTM and highly irregular and discontinuous, locally 'disappearing'.

A 'disappearing' watercourse is one which has virtually lost its drainage functions. Its surface is fully covered by plants. This type of watercourse does not significantly affect the surface lowering of the groundwater level; neither does it contribute to drying its neighbouring habitats. Its shores are practically unrecognisable or strongly obliterated from the DTM.

A 'bushy' course is covered by bushy vegetation or patches of shrubbery. They usually tend to be extinct throughout the flume and have developed land-based, moisture-loving vegetation. Like 'disappearing' watercourses, they do not play a role in drainage. The shores of these courses are generally unrecognisable on the DTM.

A 'wooded' watercourse, in terms of its geometry, is not significantly different from a 'bushy' watercourse. However, it is covered by woody vegetation, which may suggest that these streams lost their functionality much earlier than the previously mentioned classes. Similarly to 'bushy' streams, they are usually unrecognisable on the DTM.

'Underneath' watercourses are the sections of drainage networks which are located under the ground in the form of closed channels. They may be sections of ditches, closed-in culverts or crossing roads. Due to their nature, it is neither possible to see the banks on the DTM nor to define their geometry.

The presence of water was classified on the near infra-red pictures, where it was recognised in the form of a dark blue pixel. This classification was made exclusively for the year 2015 .

\section{Research results}

Qualitative analysis of changes

Comparing the databases of watercourses obtained for both research years, it was established that the qualitative assessment of changes in the river network, in the context of their condition and width, is possible. Changes in the river network are classified in terms of nature: deterioration, no changes or no improvements (Figure 2-a.). Analogously, change in width is classified as the change in its increase (Figure 2-b.). Based on the presence of water in 2015 , it was possible to evaluate the activity of the drainage system. In this case, it was assumed that the track carrying the water meets the established economic functions.

\section{Quantitative analysis of changes}

Using the previously obtained information, the number and percentage of courses was determined where the state - in the sense of drainage function - had improved, worsened or remained unchanged. The numeric data referred to the position of watercourses within certain protected areas. We also counted the number of courses where the width had increased, decreased or remained unchanged, as well as the number of courses which were not transporting water in 2015. It can be presumed that these watercourses have lost their drainage functions.

\section{Changes in watercourse conditions}

The changes were analysed for 4,317 sections of the watercourses. An improvement was observed in 432 sections, which represent nearly $10 \%$ of the total number (Table 1 ). The vast majority of these sections were technical courses of 'Krakulice' 



Figure 2. Qualitative analysis of changes (designed by M. Góraj) 
peat mine or streams that have undergone maintenance works. As a result, they have become operational (253 originally 'overgrown' track sections and 46 periodically overgrowing) (Table 2).

A worsening condition was detected in 1,245 sections of the watercourses, which is approximately $29 \%$ of all courses covered by the analysis (Table 1). The majority were watercourses which had been subjected to degenerative processes over an extended period (482 originally 'overgrown', nowadays 'disappearing'; 151 originally periodically 'overgrown', now completely 'overgrown'), as well as those which were originally classified as 'maintained' streams, now as 'overgrown' (183) or 'disappearing' (120) (Table 2).

The clear majority of sections are those that have not changed in state in the last 20 years $-2,640$ sections, which is about $61 \%$ (Table 1). They were mainly covered by forests $(1,300$ sections), usually regularly 'maintained' (620 sections), or 'overgrown' with slow-running degenerative processes (376 sections) (Table 2).

Considering the location of the analysed watercourse sections in terms of the districts of Słowiński National Park, we can see that the highest percentage of watercourses with an improved condition is located beyond the protected areas almost $20 \%$ of watercourses (Figure 3 ). This group also exhibits one of the lowest amounts of deteriorated watercourses - only around $16 \%$ (Figure 3). Most of them are technical courses of the 'Krakulice' peat mine. On the other hand, there is the protected area of Żarnowska, in which approximately $5 \%$ of watercourses were identified to have an improved condition, while nearly $50 \%$ of the courses deteriorated.

The largest share of watercourses that have not changed is situated in the protective districts in the north of Słowiński

Table 1. Changes in the state of watercourses - general

\begin{tabular}{|c|c|c|}
\hline $\begin{array}{c}\text { Changes in the state of } \\
\text { watercourses }\end{array}$ & Number & $\begin{array}{c}\text { Percentage } \\
{[\%]}\end{array}$ \\
\hline Improvement & 432 & 10 \\
No change & 2,640 & 61 \\
Worsening & 1,245 & 29 \\
Total & 4,317 & 100 \\
\hline
\end{tabular}

Table 2. Changes in the state of watercourses - details
National Park - primarily Rąbka, with up to $95 \%$ of the sections of watercourses, the protective area of Lake Gardno and Łebsko with $75 \%$, and Smołdziński forest with $74 \%$.

\section{Width changes of watercourses}

Changes in channel width were analysed for 2,701 sections of the watercourses. The minimum value at which the change is substantial was assumed as $0.5 \mathrm{~m}$. In the case of 131 watercourses, a decreased channel width was observed, with an average change value of $1.37 \mathrm{~m}$ (Table 3). A lack of significant changes was identified in 2,375 sections, which is around $88 \%$ of all analysed watercourses (Table 3 ). A width increase occurred in 195 sections, where the width increased by an average of 1.24 m (Table 3).

Overall, in the analysed area, the width of the watercourses increased by an average level of $3 \mathrm{~cm}$. If, however, the set of analysed courses situated outside the protective districts was rejected, this change decreased in value to $-3 \mathrm{~cm}$ (Table 4). The highest share of watercourses with an increased width was clearly found in the watercourses located outside the protective areas - around $34 \%$ (Figure 4).

However, no width increase was observed for the watercourses located in the Żarnowska and Rąka protection districts. The largest share of watercourses with sediment beds can be identified in Kluki (9\%) and Rowy (7\%) (Figure 4). The lowest percentage of watercourses where the riverbed has risen can be identified in Smołdziński Forest $(0.4 \%)$ and Żarnowska $(0.5 \%)$ (Figure 4). The highest average change $-0.33 \mathrm{~m}$ - occurred in the set of courses situated outside the protection zones is (Table 4). The lowest average width change of watercourses located in the Rąbka protective district can be estimated as $-0.14 \mathrm{~m}$ (Figure 4).

The presence of water in watercourses

The analysis of the presence of water, carried out based on the interpretation of the near infra-red images, made it possible to identify the courses that do not currently have any economic functions - transporting water, for example. The study was performed for 2,701 courses where more than a half $(1,589$ or $59 \%$ ) proved to be functional (transporting water) and 1,112 (about 41\%) turned out to be non-functional (Table 5).

The largest share of water-transporting watercourses occurs in the protective districts: Rąbka (86\%) and the surrounding area of lakes Gardno and Łebsko (76\%) (Figure 5).

\begin{tabular}{|c|c|c|c|c|c|c|c|c|}
\hline \multirow{2}{*}{\multicolumn{2}{|c|}{$\begin{array}{l}\text { Changes in the state of } \\
\text { the watercourses }\end{array}$}} & \multicolumn{7}{|c|}{2015} \\
\hline & & \multirow{2}{*}{$\frac{\text { maintained }}{620}$} & \multirow{2}{*}{$\begin{array}{c}\text { periodically } \\
\text { overgrown }\end{array}$} & \multirow{2}{*}{$\begin{array}{c}\text { overgrown } \\
183\end{array}$} & \multirow{2}{*}{$\begin{array}{c}\text { disappearing } \\
120\end{array}$} & \multirow{2}{*}{$\begin{array}{c}\text { bushed } \\
3\end{array}$} & \multirow{2}{*}{$\begin{array}{c}\text { wooded } \\
36\end{array}$} & \multirow{2}{*}{$\begin{array}{c}\text { underground } \\
0\end{array}$} \\
\hline \multirow{7}{*}{$\stackrel{\mathscr{\circ}}{\mathscr{\circ}}$} & maintained & & & & & & & \\
\hline & $\begin{array}{l}\text { periodically } \\
\text { overgrown }\end{array}$ & 46 & 33 & 151 & 80 & 4 & 46 & 0 \\
\hline & overgrown & 253 & 78 & 376 & 482 & 1 & 88 & 0 \\
\hline & disappearing & 0 & 0 & 4 & 90 & 0 & 1 & 0 \\
\hline & bushed & 0 & 0 & 0 & 0 & 2 & 0 & 0 \\
\hline & wooded & 10 & 12 & 18 & 7 & 4 & 1,300 & 0 \\
\hline & underground & 0 & 0 & 0 & 0 & 0 & 0 & 219 \\
\hline
\end{tabular}


MISCELLANEA GEOGRAPHICA - REGIONAL STUDIES ON DEVELOPMENT

Vol. 21 • No. 4 • 2017 • pp. 197-204 • ISSN: 2084-6118 • DOI: 10.1515/mgrsd-2017-0019

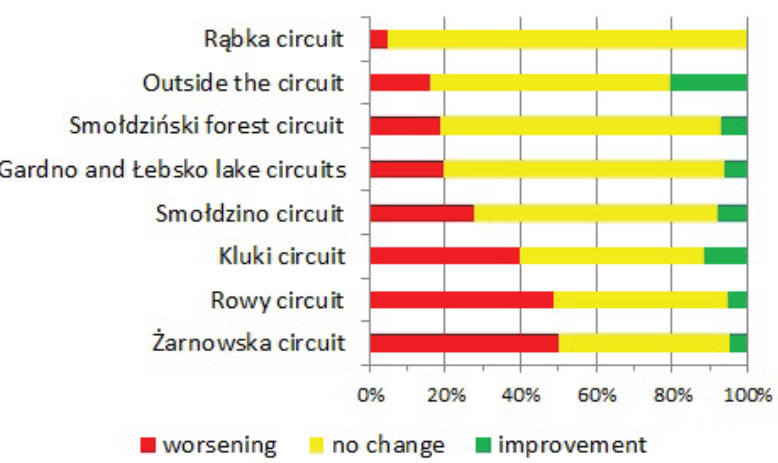

Figure 3. Changes in the state of the watercourses within the protection circuits

Table 3. Changes in the width of the watercourses - general

\begin{tabular}{|c|c|c|c|}
\hline $\begin{array}{c}\text { Changes in the width } \\
\text { of the watercourses }\end{array}$ & Number & $\begin{array}{c}\text { Mean value } \\
{[\mathrm{m}]}\end{array}$ & $\begin{array}{c}\text { Percentage } \\
{[\%]}\end{array}$ \\
\hline Increase & 195 & 1.24 & 7 \\
\hline No change & 2,375 & 0.00 & 88 \\
\hline Decrease & 131 & -1.37 & 5 \\
\hline Total & 2,701 & 0.02 & 100 \\
\hline
\end{tabular}

Table 4. Mean changes in the width of the watercourses within the protection circuits

\begin{tabular}{|c|c|}
\hline Protected region & $\begin{array}{c}\text { Mean value of } \\
\text { change [m] }\end{array}$ \\
\hline Outside the district & 0.33 \\
\hline Lake districts & 0.04 \\
\hline Smołdziński Forest district & 0.01 \\
\hline Żarnowska district & -0.01 \\
\hline Smołdzino district & -0.01 \\
\hline Kluki district & -0.07 \\
\hline Rowy district & -0.03 \\
\hline Rąbka district & -0.14 \\
\hline Total, 'outside the district' class & 0.03 \\
\hline Total, without 'outside the district' class & -0.03 \\
\hline
\end{tabular}

Table 5. Presence of water in the watercourses - general

\begin{tabular}{|c|c|c|}
\hline $\begin{array}{c}\text { Does the watercourse } \\
\text { transport water? }\end{array}$ & Count & $\begin{array}{c}\text { Percentage } \\
{[\%]}\end{array}$ \\
\hline Yes & 1,589 & 59 \\
\hline No & 1,112 & 41 \\
\hline Total & 2,701 & 100 \\
\hline
\end{tabular}

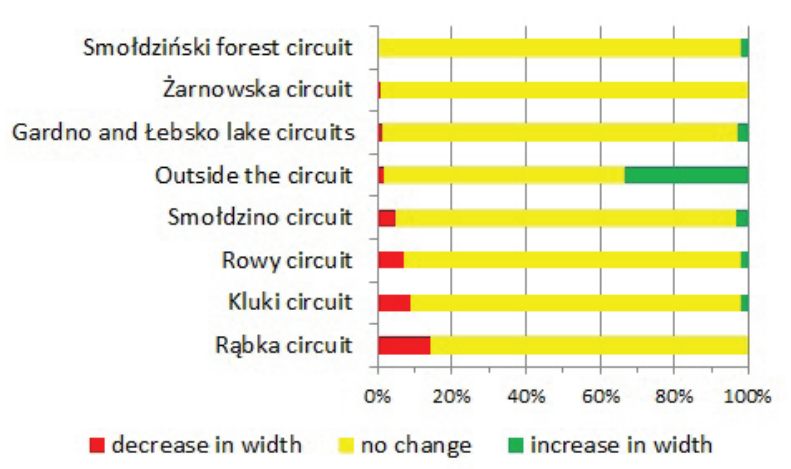

Figure 4. Qualitative changes in the width of watercourses within the protection circuits

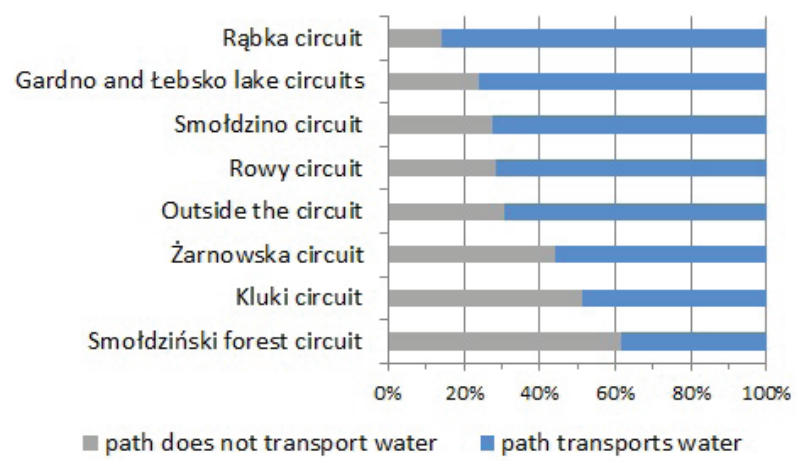

Figure 5. Presence of water in the watercourses within the protection circuits

The largest share of non-water-transporting watercourses was identified in the regions of Smołdziński forest $(62 \%)$ and Kluki (51\%) (Figure 5).

\section{Synthetic description of the hydrography network changes}

Regarding the 2,701 sections of the analysed watercourses for which it was possible to describe all hydro-morphological features, it is possible to determine the prevailing trends of the processes that have transformed the hydrographic network in Słowiński National Park.

In the case of $25 \%$ (675) of the tested watercourse sections transporting water, no change was observed in their condition or width (Table 5). More than 22\% (606 sections) of the examined courses are identified as deteriorated, combined with an absence of width change and a loss of water transporting function.

A deterioration in condition with no change in channel width and the preservation of the water transportation function was observed for 480 watercourses, which is nearly $18 \%$ of all the courses included in the analysis.

The fourth largest group of watercourses contains those whose condition and channel width have not changed and for which the transportation of water is 'maintained'. This group consists of 357 watercourses - about $13 \%$ of all the courses covered by the analysis.

Referring the above-mentioned results to the relative contribution of different watercourse groups, in terms of different protection units, a considerable influence can be observed of the location of watercourses on their described attributes (Figure 2). 
Table 6. Changes in the hydrographic network of Słowiński National Park

\begin{tabular}{|c|c|c|c|c|c|c|c|c|c|c|}
\hline \multicolumn{3}{|c|}{$\begin{array}{l}\text { Change in: state, width, } \\
\text { presence of water [\%] }\end{array}$} & \multirow{2}{*}{$\begin{array}{c}\text { Lakes } \\
\text { region }\end{array}$} & \multirow{2}{*}{$\begin{array}{c}\begin{array}{c}\text { Kluki } \\
\text { region }\end{array} \\
6\end{array}$} & \multirow{2}{*}{$\begin{array}{c}\begin{array}{c}\text { Rąbka } \\
\text { region }\end{array} \\
0\end{array}$} & \multirow{2}{*}{$\begin{array}{c}\text { Rowy } \\
\text { region }\end{array}$} & \multirow{2}{*}{$\begin{array}{c}\text { Smołdzino } \\
\text { region }\end{array}$} & \multirow{2}{*}{$\begin{array}{c}\text { Smołdziński } \\
\text { forest region }\end{array}$} & \multirow{2}{*}{$\begin{array}{c}\begin{array}{c}\text { Żarnowska } \\
\text { region }\end{array} \\
0\end{array}$} & \multirow{2}{*}{$\begin{array}{c}\text { Outside } \\
\text { the } \\
\text { region }\end{array}$} \\
\hline \multirow{6}{*}{ WS } & \multirow{2}{*}{ DW } & $\mathrm{NW}$ & & & & & & & & \\
\hline & & W & 1 & 4 & 14 & 0 & 5 & 0 & 1 & 0 \\
\hline & \multirow{2}{*}{$\mathrm{NC}$} & NW & 15 & 23 & 14 & 15 & 10 & 41 & 33 & 20 \\
\hline & & $\mathrm{W}$ & 9 & 13 & 0 & 34 & 18 & 14 & 35 & 9 \\
\hline & \multirow{2}{*}{ IW } & NW & 0 & 1 & 0 & 0 & 0 & 1 & 0 & 1 \\
\hline & & W & 0 & 0 & 0 & 0 & 0 & 0 & 0 & 0 \\
\hline \multirow{6}{*}{ NCS } & \multirow{2}{*}{ DW } & NW & 0 & 0 & 0 & 3 & 0 & 0 & 0 & 0 \\
\hline & & W & 0 & 2 & 0 & 0 & 0 & 0 & 0 & 2 \\
\hline & \multirow{2}{*}{ NC } & NW & 8 & 17 & 0 & 7 & 15 & 17 & 9 & 10 \\
\hline & & W & 56 & 20 & 71 & 31 & 44 & 14 & 17 & 21 \\
\hline & \multirow{2}{*}{ IW } & NW & 1 & 0 & 0 & 0 & 0 & 1 & 0 & 0 \\
\hline & & W & 1 & 0 & 0 & 0 & 2 & 0 & 0 & 2 \\
\hline \multirow{6}{*}{ IS } & \multirow{2}{*}{ DW } & NW & 0 & 0 & 0 & 0 & 0 & 0 & 0 & 0 \\
\hline & & W & 0 & 0 & 0 & 0 & 0 & 0 & 0 & 0 \\
\hline & \multirow{2}{*}{$\mathrm{NC}$} & NW & 0 & 3 & 0 & 0 & 3 & 2 & 2 & 0 \\
\hline & & W & 8 & 8 & 0 & 4 & 4 & 9 & 3 & 4 \\
\hline & \multirow{2}{*}{ IW } & NW & 0 & 0 & 0 & 0 & 0 & 0 & 0 & 0 \\
\hline & & W & 0 & 1 & 0 & 1 & 0 & 0 & 0 & 32 \\
\hline
\end{tabular}

Legend:

WS - worsening of state; NCS - no change in state; IS - improvement of state

DW - decrease in width; NC - no change in width; IW - increase in width

NW - no water; W - water

The courses with improved condition and maintained water transport constitute only $6 \%$ of all analysed courses (Figure 5). However, they belong to the largest group of the courses located outside the protection zone (33\% of courses). Those courses located in the legally protected neighbourhood of Słowiński National Park are mostly elements of the functional drainage system of the 'Krakulice' peat mine, which requires the maintenance of a high standard of course health (overall condition and width).

The courses where neither state nor width has changed and the transport of water has been preserved are the predominant group of the protection zones: Rąbka (71\%), lakes Gardno and Łebsko (56\%), Smołdzino (40\%), Rowy (31\%) and Kluki (20\%). Moreover, there are several such courses located outside the protection zones (21\%) (Table 6).

Deterioration observed in the absence of width changes, combined with a lack of water transport, is best recognised for the Smołdziński Forest (41\%), Żarnowska (33\%) and Kluki (23\%) regions. There is also a significant number of these courses located outside the protection zones (20\%) (Table 6). Deteriorated courses with an unchanged width and maintained water transport make up the largest group in the protection zones of Żarnowska (35\%) and Rowy (34\%) (Table 6).

\section{Analysis of the results}

The obtained results seem to be consistent with the authors' general assumptions. They indicate that the areas covered by stronger restrictions in terms of nature protection are characterized by a worse condition of drainage facilities. Such differences are particularly visible when we compare the condition of watercourses from the protection zone of Żarnowska with watercourses located in the adjacent south-eastern areas influenced by the exploitation of the 'Krakulice' peat mine. This conclusion coincides with the findings of Utracka-Minko and Stanko (2005).

The changes detected as a result of the research are more visible in the areas outside Słowiński National Park. These results are consistent with similar research conducted in Forenza Municipality by Statuto et al. (2015).

One of the major drawbacks of the utilized method, particularly in the context of detecting the changes in channel width, is the range of spatial resolutions of the utilized source materials. For the interpretation of the orthophoto maps from 1996, a picture of significantly lower resolution was used than during the analysis of near infra-red from 2015. Moreover, for older pictures, there is no reference DTM and hence, the relevant analysis of changes in channel width can be influenced by significant errors - especially the underestimation or overestimation of channel widths for 1996. Nonetheless, the obtained results confirm the earlier assumptions. The existence has been proved of a far smaller proportion of watercourses whose width increased in the protection zones compared to the courses from outside.

Another disadvantage of this method is the fact that it does not allow analyses to be conducted of channel changes and the presence of water in shrubby or wooded watercourses. This resulted in the exclusion of these types of courses from further 
analysis. On the other hand, the indisputable advantage was its efficiency compared to time-consuming field research. It also allows us to continuously control the measurement accuracy, which can be difficult for other unsupervised methods. The results are characterized by a high level of detail; furthermore, the obtained information is easily interpretable and allows for an easy evaluation of preventive measures within anthropogenically converted wetlands.

\section{Conclusions}

Based on the obtained results, the following conclusions can be drawn:

- Courses located outside the protective areas are subjected to significant anthropogenic pressure. This may lead to the further degradation of wetland communities in Słowiński National Park, as well as reducing the effectiveness of the reclamation of peatlands located within the protection zones (for example, in Żarnowska, due to drainage work related to the activity of the 'Krakulice' mine).
- Locally, in Słowiński National Park, slow-paced processes of spontaneous re-naturalisation are taking place which may result in a partial restoration of the original groundwater condition (especially in the Kluki, Rąbka, Rowy and Żarnowska protection zones).

- In Słowiński National Park, there a large proportion of watercourses have no water transport function (41\%), which indicates the existence of a natural degeneration process of artificial watercourses. This may lead to the local recovery of water conditions and a halt to the negative processes of bog rotting.

- Generally, in Słowiński National Park, there is a dominance of watercourses which did not change significantly during the analysed period, especially in the context of channel width.

- Particularly strong degenerative processes, in terms of the deterioration of watercourse condition, are recognisable in the Żarnowska, Rowy and Kluki protection zones.

\section{References}

Adrian, M 2013, Kroniki Słowińskiego Parku Narodowego, Smołdzino, Słowiński Park Narodowy.

Angermeier, P, Bledsoe, B \& Wohl, E 2005, 'River restoration”, Water Resources Research.

Barszczyńska, M, Borzuchowski, J, Kubacka, D, Piórkowski, P, Rataj, C, Walczykiewicz, T \& Woźniak, Ł 2013, 'Mapa Podziału Hydrograficznego Polski w skali 1:10 000 - nowe hydrograficzne dane referencyjne' Roczniki Geomatyki, vol. 11 , issue 3 , pp. $15-26$.

Chapman, PJ, Labadz, JC \& Holden, J 2004, 'Artificial drainage of peatlands: hydrological and hydrochemical process and wetland restoration', Progress in Physical Geography, vol. 28 , issue 1 , pp. 95-123.

Gesch, DB, Worstell, BB \& Poppenga, SK 2013, 'Hydrography change detection: the usefulness of surface channels derived form LiDAR DEMs for updating mapped hydrography', JAWRA Journal of the American Water Resources Association, vol. 49, issue 2, pp. 371-389.

Harig, AL, Bain, MB, Loucks, DP, Goforth, RR \& Mills, KE 2000, 'Aquatic ecosystem protection and restoration: advances in methods for assessment and evaluation', Environmental Science and Policy, vol. 3, pp. 89-98.

Kondolf, GM 1995, 'Five elements for effective evaluation of stream restoration', Restoration ecology, vol. 2, pp. 133136

Lipiński, J 2006, 'Zarys rozwoju oraz produkcyjne i środowiskowe znaczenie melioracji w świetle badań.' Acta Scientiarium Polonarum, vol. 5, issue 1, pp. 3-15.

Mocek, A 1978, 'Gleby o charakterze murszowym w otulinie Słowińskiego Parku Narodowego', Roczniki Gleboznawcze, vol. 29, issue 3, pp. 175-202.

Mocek, A, Dzięciołowski, W \& Tobolski, K1997, Gleby Słowińskiego Parku Narodowego w świetle historii roślinności i podłoża, Bydgoszcz, Poznań, Wydawnictwo Homini.

Nawrocki, P 2011, 'Melioracje wodne a wdrażanie przepisów europejskich', Kontrola Państwowa, vol. 1, pp. 61-89.
Przybycin, J \& Hildebrandt-Radke, I 2011, 'Zmiany sieci hydrograficznej i zalesienia a melioracje regionu środkowej Obry (centralna Wielkopolska) w świetle danych historycznych i materiału kartograficznego', Przegląd Geograficzny, vol. 83, issue 3, pp. 323-342.

Ptak, M, Illyin, LV \& Choiński, A 2012, 'Zmiany sieci hydrograficznej Łucka w świetle materiałów kartograficznych', Naukovi vydannya Skhidnoyevropeys'koho natsional'noho universytetu im. Lesi Ukrayinky, pp. 12-17.

Rokitnicka, J 2011, 'Gospodarka wodna w świetle uwarunkowań Unii Europejskiej' in Stan gospodarki wodnej w Polsce problematyka prawna i kompetencyjna (na przykładzie Dolnej Wisły), Warszawa: Zeszyty Zespołów Senackich.

Słowiński Park Narodowy 2015, ,Słowiński Park Narodowy.' Available from: <http://www.Słowińskipn.pl>. [30 August 2016].

Szatten, D 2013, 'Wpływ powstania zbiornika Koronowskiego na hydrografie obszarów przyległych', Zeszyty Naukowe Uczelnianej Rady Doktorantów UKW, vol. 1, pp.73-92.

Chlost, I 2013, 'Wpływ antropopresji na zmianę stosunków wodnych Niziny Gardneńsko-Łebskiej' in Geoekosystem Wybrzeży Morskich 2, Poznań, Biała-Góra, Uniwersytet im. Adama Mickiewicza, pp. 15-18.

Statuto, D, Cillis, G \& Picuno, P 2015, 'Historical cartography and GIS Tools for the analysis of land use and landscape changes' in Simpozij aktualni zadaci mehanizacije poljoprivrede, Opatija.

Utracka-Minko, B \& Stańko, R 2005, Waloryzacja przyrodnicza oraz program ochrony wybranych mokradeł Słowińskiego Parku Narodowego - obwód ochronny Żarnowska, obwód ochronny Kluki, obwód ochronny Rowy (Polder Gardna IX), Słupsk.

Zaigham, NA \& Mahar, GA 2015, 'Examining spatiotemporal change detection in the Indus River Delta with the Help of Satellite data', Arabian Journal for Science and Engineering, vol. 40, issue 7, pp. 1933-1946. 